\title{
Smart Farmer Sebagai Optimalisasi Digital Platform Dalam Pemasaran Produk Pertanian Pada Masa Pandemi Covid-19
}

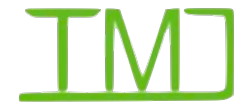

\author{
Blasius Erik Sibarani \\ Universitas Negeri Medan \\ E-mail:blasiussibarani@gmail.com
}

Sibarani, B. E. (2021). Smart Farmer Sebagai Optimalisasi Digital Platform Dalam Pemasaran Produk Pertanian Pada Masa Pandemi Covid-19. Technomedia Journal, 6(1 Agustus).

https://doi.org/10.33050/tmj.v6i01 Agustus.1545

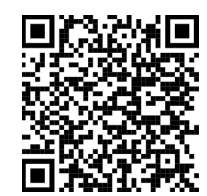

Notifikasi Penulis

11 Februari 2021

Akhir Revisi

04 Mei 2021

Terbit

01 Agustus 2021

\section{ABSTRAK}

Pertanian menjadi salah satu sektor yang dapat mendorong kondisi perekonomian bangsa pada masa pandemi covid-19, karena sektor pertanian menjadi salah satu sektor yang menyumbangkan PDB (Produk Domestik Bruto). Akan tetapi, pada masa pandemi covid-19 saat ini masih banyak masyarakat petani yang kekurangan akses untuk melakukan pemasaran produk pertaniannya. Pemasaran menjadi salah satu faktor dalam meningkatkan penjualan para masyarakat petani. Tanpa adanya akses pemasaran yang mudah akan menyebabkan produk petani tidak dikenal oleh masyarakat luas sehingga penjualan para petani tidak meningkat yang akan berdampak pada perekonomian. Tentunya keadaan tersebut sangat perlu diperbaiki, agar produk petani dapat dikenal dan bisa dijual keluar wilayah agar bisa mendorong tingkat perputaran ekonomi di masa pandemi covid-19. Salah satu usaha memperbaikinya yaitu dengan membangun sebuah digital platform yang dapat digunakan oleh petani untuk memasarkan produknya. Adapun tujuan dari penulisan ini adalah memberikan gagasan dalam pemasaran produk bagi petani di masa pandemi covid-19 untuk bisa menopang ekonomi bangsa. Adapun manfaat yang diperoleh oleh para petani dan juga para konsumen secara langsung dan tidak langsung, terutama dari semakin luasnya akses pemasaran hasil pertanian dapat meningkatkan permintaan produksi serta mempercepat pengadaan produksi di kalangan petani dan juga harga yang ditawarkan ke konsumen sesuai dengan harga pasar sehingga penjualan hasil pertanian bisa meningkat dan menguntungkan petani.

Kata Kunci: Covid-19, Digital Platform, Pemasaran, Pertanian

\section{ABSTRACT}

Agriculture is one of the sectors that can boost the nation's economic condition during the Covid-19 pandemic, because the agricultural sector is one of the sectors that contributes to GDP (Gross Domestic Product). However, during the covid-19 pandemic, there are still many farming communities who lack access to marketing their agricultural products. Marketing is one of the factors in increasing the sales of the farming community. Without easy marketing access, farmers 'products are not known by the wider community so that farmers' sales do not increase which will have an impact on the economy. Of course, this situation really needs to 
be improved, so that farmer products can be recognized and can be sold outside the region so that it can encourage the level of economic turnover during the Covid-19 pandemic. One of the efforts to improve this is by building a digital platform that can be used by farmers to market their products. The benefits obtained by farmers as well as consumers directly and indirectly, especially from the wider access to marketing agricultural products can increase production demand and accelerate the procurement of production among farmers and also the price offered to consumers according to market prices so that sales agricultural yields can increase and benefit farmers. The purpose of this paper is to provide ideas in product marketing for farmers during the Covid-19 pandemic to be able to sustain the nation's economy.

Kata Kunci: Covid-19, Digital Platform, Marketing, Agriculture

\section{PENDAHULUAN}

Pada saat ini, semua negara mengalami gejolak akibat wabah pandemi covid-19. Sejak diumumkannya covid-19 sudah meluas dan memakan korban yang banyak serta mengakibatkan semua negara mengalami kesulitan. Semua sektor dalam suatu negara mengalami penurunan akibat pandemi. Salah satu sektor yang mengalami dampak akibat pandemi covid-19 ialah sektor pertanian hal ini berdasarkan data dari litbang pertanian. Pandemi covid-19 membawa dampak negatif terhadap negara Indonesia. Dimana berdasarkan data laporan Badan Pusat Statistik (BPS) pada Agustus kuartal II 2020 pertumbuhan ekonomi minus 5,32\%, sebelumnya pada kuartal I 2020 pertumbuhan ekonomi 2,97\%. Indonesia yang notabenenya merupakan salah satu negara agraris dimana, sebagian besar penduduknya tinggal di pedesaan dengan mata pencaharian sebagai petani. Penduduk Indonesia pada umumnya mengkonsumsi hasil pertanian untuk makanan pokok mereka. Pertanian di Indonesia perlu ditingkatkan produksinya semaksimal mungkin menuju swasembada pangan akan tetapi, untuk mencapai hal tersebut memiliki tantangan karena luas wilayah pertanian yang semakin lama semakin berkurang, hal ini sesuai data dari Badan Pusat Statistik (BPS) Indonesia dimana tahun 2013 luas lahan sebesar 8.128.499 hektar, kemudian tahun 2014 luas lahan sebesar 8.111.593 hektar, sedangkan pada tahun 2015 luas lahan sebesar 8.087.393 hektar, dari data terlihat jelas bahwa luas lahan semakin berkurang, ada penyimpangan iklim, pengembangan komoditas lain, teknologi yang belum modern, dan masalah yang satu ini adalah masalah yang sering meresahkan hati para petani yaitu hama dan penyakit yang menyerang tanaman yang dibudidayakan. Pertanian adalah salah satu komoditas unggulan di Indonesia, hal dibuktikan dengan dimana pemerintah Indonesia mengandalkan sektor pertanian untuk menggenjot produk domestik bruto (PDB) tahun 2021. Tingginya permintaan tersebut menjadikan sektor pertanian sangat memiliki peran vital dalam upaya meningkatkan perekonomian Indonesia pada masa pandemi covid-19. Akan tetapi disisi lain, terkadang banyak kelompok masyarakat tidak diuntungkan akibat permasalahan yang timbul karena pemasaran produk pertanian tersebut yang cukup minim sehingga produk mereka jarang dikenal oleh kalangan masyarakat luas. Berdasarkan data Census Agricultural Survey bahwa pada tahun 2018 jumlah masyarakat yang bermata pencaharian sebagai petani berkisar 70 Juta penduduk yang dimana didominasi oleh pertanian bidang padi. Namun ternyata, dengan banyaknya masyarakat yang bermata pencaharian sebagai petani, masyarakat lebih cenderung menghabiskan hasil pertaniannya begitu saja tanpa memberikan dampak positif bagi perekonomian masyarakat. Alhasil, produk pertaniannya tidak bisa dikenal oleh kalangan masyarakat diluar desa serta hasil pertaniannya banyak yang disimpan ditempat para petani sehingga produknya menjadi rusak. Mengapa hal 
demikian bisa terjadi?, karena masyarakat tidak memanfaatkan era teknologi saat ini. Statement ini terbukti sesuai data dari Survei Pertanian Antar Sensus pada tahun 2018 (SUTAS 2018) mengkonfirmasi bahwa dari sekitar 33 jutaan petani, hanya 13 persen atau sekitar 4 jutaan yang menggunakan internet, itu artinya bahwa masih sedikit masyarakat petani yang memanfaatkan teknologi terlebih di masa pandemi covid-19.

\section{PERMASALAHAN}

Disini penulis memfokuskan pada suatu Desa yaitu Desa Tomok Parsaoran yang menjadi subjek penelitian. Desa Tomok Parsoran merupakan sebuah desa yang terletak di Kecamatan Simanindo Kabupaten Samosir Provinsi Sumatera Utara yang dimana mayoritas penduduknya bermata pencaharian sebagai petani sehingga aktivitas dan hasil ekonomi yang dihasilkan juga adalah mayoritas komoditas hasil pertanian. Adapun komoditas hasil pertanian yang dihasilkan dari desa ini adalah sebagai berikut:

Tabel 1. Komoditas Hasil Pertanian Desa Tomok Parsaoran

\begin{tabular}{|l|l|c|c|}
\hline No. & Jenis Tanaman & Produksi (ton) & Persentase (\%) \\
\hline 1. & Padi sawah & 200,90 & 36,05 \\
\hline 2. & Jagung & 13,12 & 2,35 \\
\hline 3. & Ubi kayu & 1,40 & 0,25 \\
\hline 4. & Kacang tanah & 0,12 & 0,02 \\
\hline 5. & Kelapa & 118,10 & 21,19 \\
\hline 6. & Kopi & 74,00 & 13,28 \\
\hline 7. & Cokelat & 83,10 & 14,91 \\
\hline 8. & Kemiri & 66,60 & 11,95 \\
\hline
\end{tabular}

Sumber: Badan Pusat Statistik Kabupaten Samosir 2017

Dari tabel diatas dapat disimpulkan bahwa komoditas pertanian yang paling banyak dihasilkan adalah padi sawah sebanyak 36,05\%, jagung 2,35\%, ubi kayu 0,25\%, kacang tanah $0,02 \%$, kelapa $21,19 \%$, kopi $13,28 \%$, cokelat $14,91 \%$ dan kemiri $11,95 \%$. Dari hasil pertanian tersebut dapat disimpulkan bahwa hasil pertanian yang paling banyak dihasilkan adalah padi sawah, yaitu sebesar $36,05 \%$ dan yang paling sedikit adalah kacang tanah, yaitu sebesar $0,02 \%$.

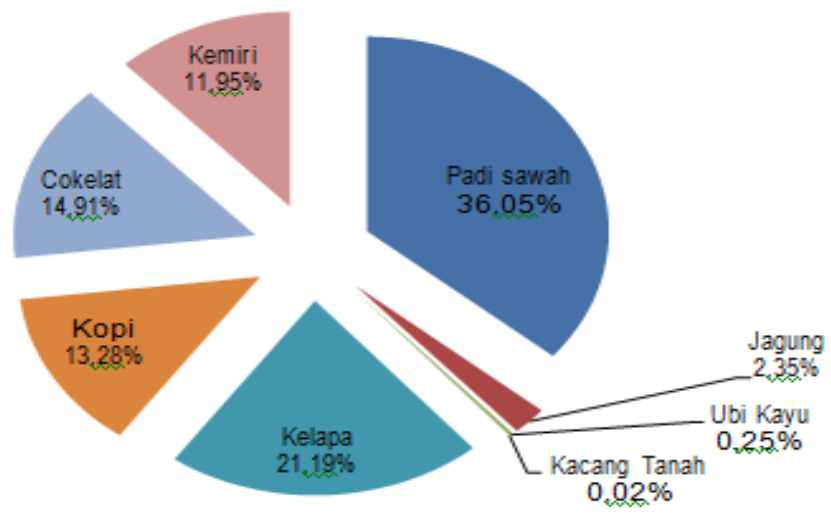

Sesuai dengan pengamatan penulis bahwa petani Desa Tomok Parsaoran dalam memasarkan produk pertaniannya masih di pasar lokal, yang artinya bahwa mereka masih memasarkan 
produk secara konvensional. Petani belum memanfaatkan era teknologi sekarang ini sehingga mereka tidak memperoleh pendapatan yang lebih. Padahal kita tahu potensi pemanfaatan teknologi di Era Society 5.0 terlebih pada masa pandemi covid-19 sangatlah besar. Jika seperti ini terus, maka perekonomian akan sulit untuk berkembang dan hasil pertanian mereka akan sulit terjual karena pangsa pasar mereka masih disekitar wilayah Tomok Parsaoran. Hal ini tidak dapat dibiarkan terus menerus dan harus diupayakan sebuah inovasi untuk membantu petani dalam pemasaran produk pertanian mereka. Tujuan dari penulisan ini adalah memberikan gagasan dalam pemasaran produk bagi petani di masa pandemi covid-19 untuk bisa menopang ekonomi bangsa.

\section{METODOLOGI PENELITIAN}

\section{A. Jenis Penelitian}

Jenis penelitian yang akan dilakukan adalah research and development. Melakukan pengembangan terhadap aplikasi agar tercipta siklus transaksi yang sederhana. Menurut Johar (2014) metode penelitian $\mathrm{RnD}$ (Research and Development) adalah metode penelitian yang digunakan dalam menghasilkan produk dengan menggunakan alat yang sudah diuji coba dan dilihat tingkat keefektifannya. Jadi, penelitian $\mathrm{RnD}$ pada dasarnya metode yang digunakan dalam menghasilkan suatu hal yang diinginkan dengan menggunakan alat atau program yang sudah ada.

\section{B. Teknik Pengumpulan Data}

Teknik pengumpulan data yang dilakukan dalam penelitian ini yaitu dengan melakukan studi pustaka yang diperoleh dari website bps samosir, buku-buku dan/ atau jurnal dalam pencarian referensi terkait pengumpulan data maupun perancangan sebuah aplikasi yang akan dibangun. Selain itu, pengumpulan data juga dilakukan dengan observasi langsung untuk mengetahui hal-hal tertentu yang diamati.

\section{Perancangan Sistem}

Menurut Mulyani (2017) pengertian Perancangan sistem adalah penentuan proses dan data yang diperlukan oleh sistem baru. Tujuan dari perancangan sistem adalah untuk memenuhi kebutuhan pemakai sistem serta untuk memberikan gambaran yang jelas dan rancang bangun yang lengkap. Sedangkan Muharto (2016) mendefinisikan perancangan sistem perancangan sistem adalah suatu fase dimana diperlukan suatu keahlian perancangan untuk elemen-elemen komputer yang akan mengunakan sistem yaitu pemilihan peralatan dan program komputer untuk sistem yang baru. Dari pengertian para ahli diatas, maka perancangan sistem merupakan suatu perancangan yang menitikberatkan pada elemen ataupun gambaran dalam program yang akan dibuat.

\section{Perancangan Aplikasi}

Aplikasi adalah salah satu unit perangkat lunak yang dibuat untuk melayani kebutuhan akan beberapa aktivitas (Supadi, 2015). Menurut Maulana dan Bunyamin (2015) aplikasi adalah program yang berisikan perintah-perintah untuk melakukan pengolahan data dengan membuat sistem atau program agar data diolah. misalnya Microsoft Word dan Microsoft Excel. Dari pendapat ahli diatas, maka dapat diartikan bahwa aplikasi adalah sebuah program yang bisa mengolah data melalui sistem yang telah terancang. 
Kemudian untuk mengetahui kelayakan penggunaan aplikasi yang dilihat dari segi kekuatan dan kelemahan, maka digunakan analisis SWOT (Strength, Weakness, Opportunity, and Threats).

\section{HASIL DAN PEMBAHASAN}

Berkembangnya teknologi dan internet pada era Society 5.0 memberikan kemudahan bagi petani untuk memasarkan produk hasil pertaniannya pada masa pandemi covid-19. Sayangnya perkembangan teknologi dan internet ini belum menyentuh dunia pertanian dengan optimal khususnya di daerah pedesaan. Petani di pedesaan banyak yang tidak mengetahui dunia digital sehingga membuat mereka tertinggal.

Penerapan teknologi informasi dan komunikasi dalam pemasaran sektor pertanian umumnya belum berkembang baik. Hal ini sesuai data dari BPS dimana jumlah petani di Indonesia yang menggunakan internet baru sekitar 4,5 juta orang, dari data tersebut dapat kita lihat bahwa penerapan teknologi dalam bidang pertanian masih rendah. Banyak kendala dan keterbatasan yang dihadapi, namun bukan berarti tidak ada kemajuan yang dibuat. Peran teknologi informasi dan komunikasi dalam pemasaran produk pangan dan pertanian adalah mewujudkan sistem pemasaran yang efisien sehingga mampu mencapai produktivitas yang lebih tinggi dan memacu pertumbuhan ekonomi.

Aplikasi Smart Farmer adalah aplikasi penyedia atau fasilitator dalam pemasaran produk pertanian. Aplikasi Smart Farmer sebagai wadah bagi para petani yang memasarkan produk pertaniannya di pasar lokal sehingga aplikasi ini semakin membuat produk pertanian menjadi bisa dipasarkan secara luas diluar daerah dan menambah pangsa pasar. Aplikasi ini nantinya akan jadi perantara dalam transaksi antara Penjual (Petani) dengan pembeli (Masyarakat non-petani). Selain peningkatan pemasaran produk pertanian, secara tidak langsung aplikasi Smart farmer juga meningkatkan jumlah pendapatan dan tentunya meningkatkan perekonomian masyarakat petani melalui peningkatan hasil pemasaran produk. Dimana, secara sinkronisasi, jika pemasaran produk pertanian semakin luas, maka otomatis pendapatan masyarakat akan meningkat dibandingkan seperti biasanya serta membawa perekonomian masyarakat lebih baik.

\section{A. Implementasi Aplikasi}

Dalam pengimplementasian aplikasi Smart Farmer, terdapat beberapa fitur yang tersedia dan bisa digunakan oleh user. Berikut proses pengimplementasian Smart Farmer:

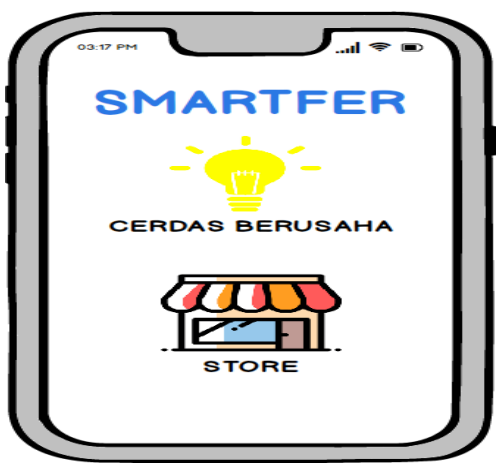

Gambar 2. Tampilan Awal Smart Farmer 
Di Tampilan awal akan menampilkan pilihan yaitu "Penjual" dan "Pembeli". Disini user tinggal memilih yang mana, apakah user sebagai penjual atau sebagai pembeli. Jika user sebagai pembeli tinggal klik "pembeli" dan jika user sebagai penjual tinggal klik "penjual".

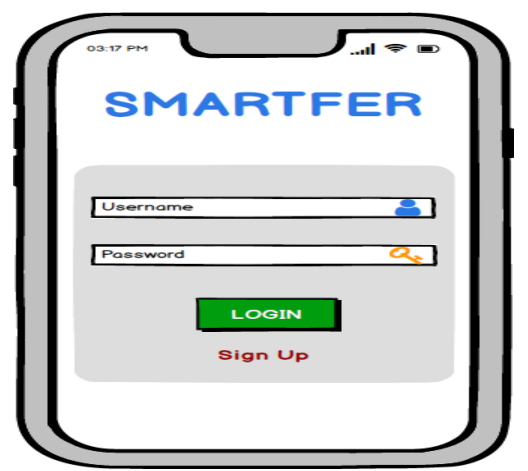

Gambar 3. Tampilan Masuk Aplikasi

Kemudian, setelah user memilih antara "penjual atau pembeli", selanjutnya kita akan diarahkan ke tampilan "Login" dan "Sign Up". Jika user sudah memiliki akun tinggal mengisi nama username dan password setelah itu klik "login" dan jika user belum punya akun tinggal daftar dengan cara klik "sign up". Setelah selesai melakukan pendaftaran akun, silahkan login dengan akun yang sudah terdaftar.

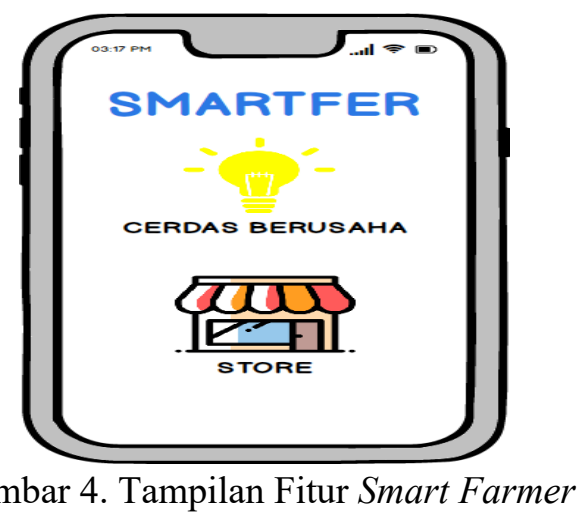

Setelah selesai login, user akan diarahkan ke tampilan menu "Cerdas Berusaha" dan "Store". Room "Cerdas Berusaha" terdiri dari dua fitur yaitu fitur "Edukasi" dan "Ruang Diskusi”, room ini dibuat untuk user yang ingin belajar mengenai pemasaran, teknik penjualan bagaimana, dan ingin berdiskusi dengan sesama user. Jika user ingin belajar mengenai materi tersebut dan ingin berdiskusi bisa silahkan klik "Cerdas Berusaha", dan jika user ingin melakukan penjualan atau pembelian produk dan melihat sejauh mana hasil penjualan, bagaimana grafik penjualannya, user tinggal klik "Store" 


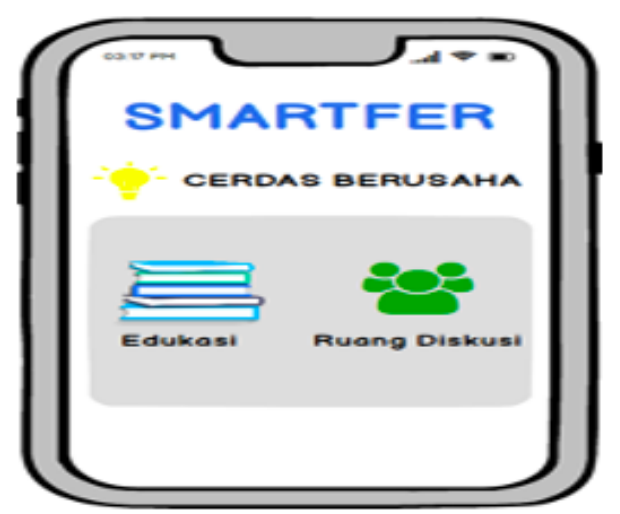

Gambar 5. Tampilan Fitur Cerdas Berusaha

Jika user memilih room "Cerdas Berusaha", maka akan diarahkan ke tampilan "Edukasi” dan "Ruang Diskusi". User jika ingin belajar pemasaran, teknik penjualan, bisa klik "Edukasi" dan user yang ingin melakukan diskusi dengan user lainnya ataupun yang ingin konsultasi bisa klik "Ruang Diskusi”.

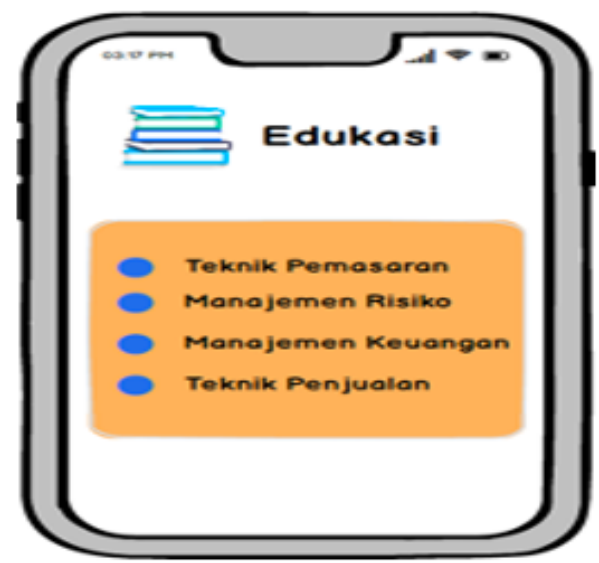

Gambar 6. Tampilan Fitur Edukasi

Kemudian jika user memilih "Edukasi", maka akan diarahkan ke tampilan Edukasi, yang dimana user bisa belajar tentang teknik pemasaran, manajemen risiko, manajemen keuangan dan teknik penjualan. Keempat pembahasan ini sangat penting dalam dunia pemasaran sehingga perlu dipahami. User tinggal memilih materi mana yang ingin dipelajari.

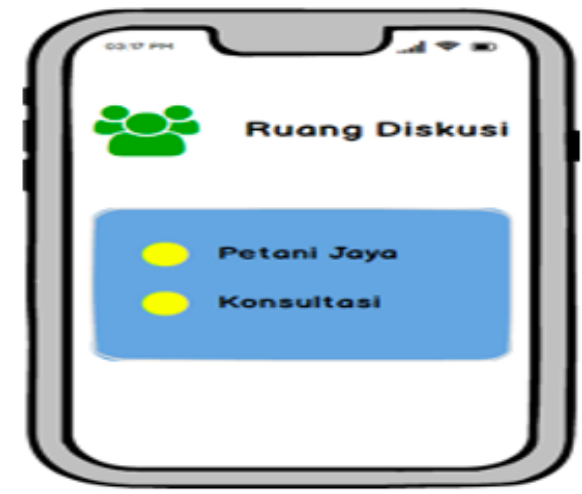

Gambar 7. Tampilan Fitur Ruang Diskusi

Kemudian jika user memilih "Ruang Diskusi", maka akan diarahkan ke tampilan "Ruang Diskusi". Disini user bebas melakukan diskusi dengan sesama user dan juga bebas 
melakukan konsultasi. Jika ingin melakukan diskusi tinggal klik "Petani Jaya" dan jika ingin melakukan konsultasi tinggal klik "Konsultasi"

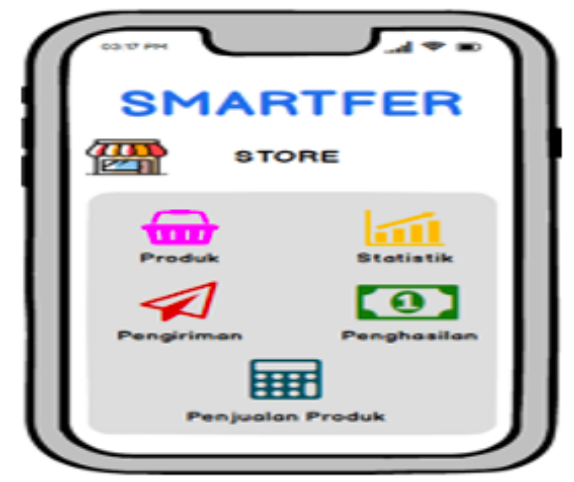

Gambar 8. Tampilan Fitur Store

Setelah tadi membahas mengenai fitur "Cerdas Berusaha", kemudian ada fitur "Store". Jika user ingin melakukan penjualan produk, melihat penghasilan, melihat statistic penjualan, melihat lokasi pengiriman dan mengecek produk yang tersedia, maka user tinggal klik fitur "Store". User akan diarahkan ke tampilan "Store", user tinggal memilih ingin melakukan operasi apa, jika ingin melihat penghasilan tinggal klik "Penghasilan", seperti itu juga untuk room yang lain.

Setelah tadi membahas mengenai fitur "Cerdas Berusaha", kemudian ada fitur "Store". Jika user ingin melakukan penjualan produk, melihat penghasilan, melihat statistic penjualan, melihat lokasi pengiriman dan mengecek produk yang tersedia, maka user tinggal klik fitur "Store". User akan diarahkan ke tampilan "Store", user tinggal memilih ingin melakukan operasi apa, jika ingin melihat penghasilan tinggal klik "Penghasilan", seperti itu juga untuk room yang lain.

\section{B. Uji Coba Smart Farmer}

Pengujian ini dilakukan untuk memastikan bahwa kinerja aplikasi dapat berfungsi sesuai dengan apa yang diharapkan. Tolok ukur yang perlu diuji yaitu tingkat keberhasilan dalam pengolahan data hasil penjualan tani desa Tomok Parsaoran, keberhasilan dalam hal pemasaran produk pertanian desa Tomok Parsaoran. Pengaruh perubahan kondisi hasil implementasi kepada masyarakat harus diperhatikan dengan serius. Pengujian akan dilakukan di desa Tomok Parsaoran. Apabila hasil yang diperoleh tidak sesuai dengan prospek maka akan dilakukan kembali tinjauan dibagian mana yang kurang, bagian mana yang menyebabkan terjadinya kekurangan smartfer dan melakukan tahap ulang pendesainan Smartfer.

\section{Dampak Inovasi Smart Farmer}

1. Manfaat dan Pengaruh dari Smart Farmer terhadap masyarakat petani 
Dengan hadirnya Smart farmer sebagai aksesibilitas sekaligus sebagai fasilitator masyarakat petani dalam pemasaran dan perdagangan hasil pertaniannya, maka beberapa manfaat yang akan diberikan kepada masyarakat petani adalah sebagai berikut:

a. Smart farmer akan menjadi sentral tempat masyarakat bermata pencaharian sebagai petani dalam memasarkan hasil produk pertaniannya.

b. Smart farmer akan menjadi pusat pertumbuhan ekonomi masyarakat petani, dimana masyarakat akan mampu mengakses fasilitas yang ada/tersedia.

c. Smart farmer akan menjadi pusat informasi produk penjualan hasil pertanian.

d. Smart farmer akan menjadi suatu wadah untuk masyarakat bermata pencaharian sebagai petani yang ingin terlibat digital trade.

e. Smart farmer akan meningkatkan jumlah pendapatan masyarakat petani

f. Produk masyarakat petani nantinya akan dikenal oleh kalangan masyarakat luas

2. Inovasi keunggulan Smart Farmer

Adapun inovasi keunggulan Smart Farmer ini adalah sebagai berikut:

a. Memastikan masyarakat petani memiliki satu akun sebagai akses bagi petani untuk memasarkan hasil produk pertaniannya dan melakukan transaksi.

b. Smart farmer akan meningkatkan aktivitas petani melalui kegiatan yang langsung dilakukan oleh masyarakat petani.

c. Transaksi dalam smart farmer cukup sederhana dan tidak rumit dipahami

d. Smart Farmer akan meningkatkan jumlah petani yang melek digital dan smart farmer akan mengoptimalisasi masyarakat petani dalam perdagangan baik lokal maupun nasional

e. Smart farmer memberikan layanan edukasi yang akan membantu mereka dalam pemasaran

produk hasil

pertaniannya.

Secara garis besar diagram alir Smart Farmer ditampilkan dalam gambar berikut: 


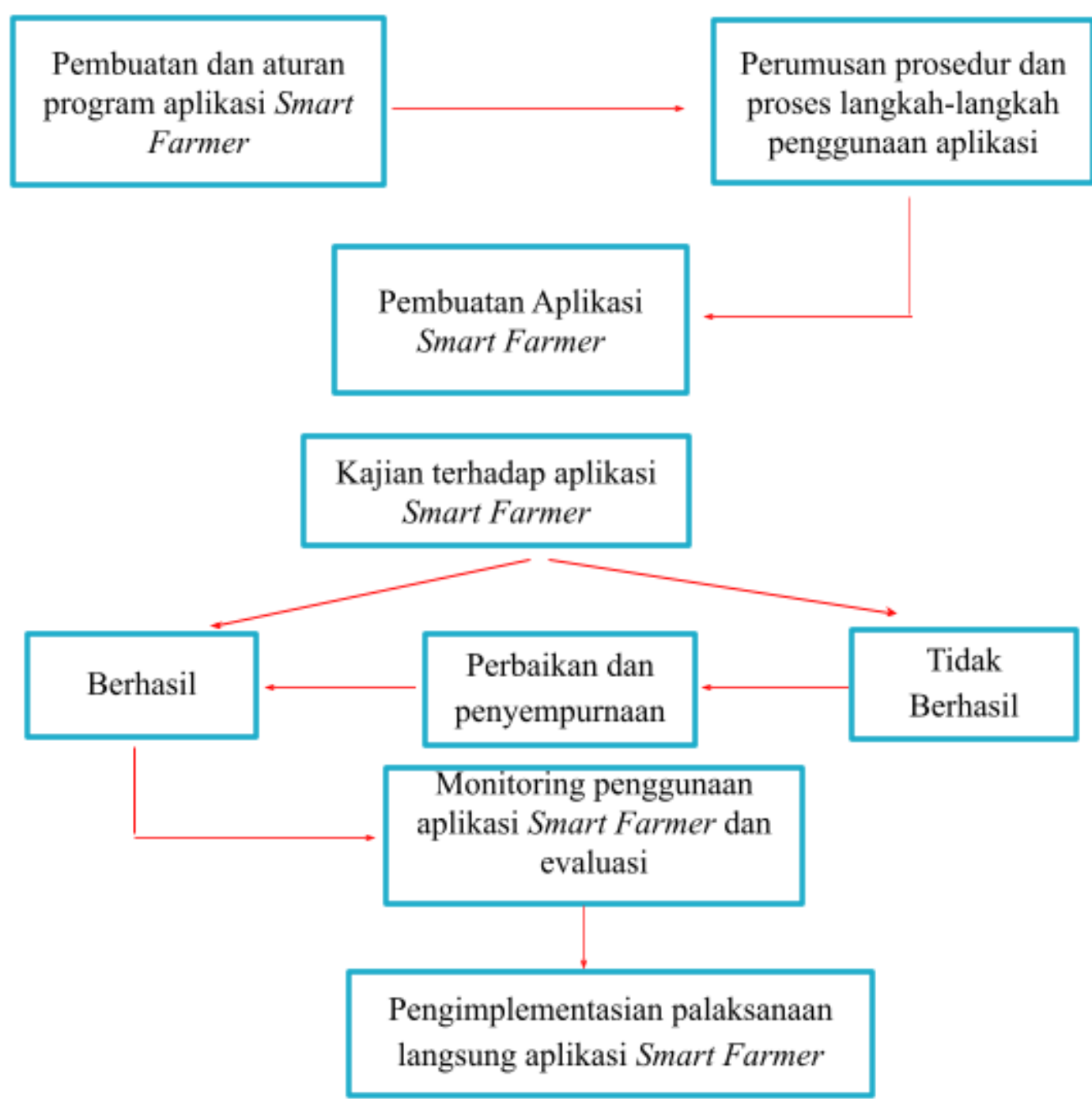

Gambar 9. Diagram Alir Smart Farmer

\section{Keterangan diagram alir:}

1) Membuat aturan program aplikasi, aturan apa saja yang harus dipatuhi para pengguna aplikasi agar tidak terjadi suatu hal yang tidak diinginkan

2) Merumuskan langkah-langkah dari penggunaan aplikasi, bagaimana prosedur dalam mengoperasikan aplikasi.

3) Melakukan pembuatan aplikasi untuk bisa digunakan

4) Melakukan kajian terhadap aplikasi yang sudah dirancang untuk melihat sejauh mana program aplikasi dijalankan

5) Jika ternyata tidak berhasil dari hasil kajian aplikasi, maka dilakukan perbaikan aplikasi agar bisa lebih baik lagi

6) Dalam tahap perbaikan, dianalisis apa yang menyebabkan kekurangan aplikasi dan kemudian memperbaikinya

7) Jika hasil kajian berhasil, maka tidak perlu dilakukan perbaikan dan penyempurnaan, cukup melakukan maintenance

8) Kemudian melakukan monitoring penggunaan aplikasi Smart Farmer dan evaluasi 
9) Setelah itu, dalam tahap akhir yaitu melakukan mengimplementasikan pelaksanaan langsung aplikasi

Smart

Farmer

\section{Analisis}

SWOT

\section{Strength:}

1. Praktis dan Inovatif

2. Terdapat fitur yang bermanfaat bagi petani

3. Proses transaksi tidak rumit

4. Model berbasis aplikasi ini belum ada sebelumnya

5. Produk petani akan terlibat dalam perdagangan baik lokal maupun nasional

6. Tidak memerlukan biaya yang banyak untuk dikeluarkan dalam proses transaksi

7. Masyarakat target dalam persentase yang tinggi, yaitu petani

8. Model berbasis aplikasi ini akan meningkatkan perekonomian para petani

9. Terdapat layanan edukasi teknik pemasaran produk

10. Terdapat layanan chat antara petani sebagai penjual dan pembeli produk

\section{Weakness:}

1. Pembuatan aplikasi membutuhkan dana yang cukup mahal

\section{Opportunity:}

1. Kebijakan pemerintah yang pro terhadap pengembangan petani.

2. Banyaknya pengguna gadget

3. Jumlah petani yang cukup banyak sehingga mendukung keberlangsungan model aplikasi

ini

\section{Threats:}

1. Adanya pola pikir imitasi dalam masyarakat petani

2. Adanya pola pikir pelaku masyarakat yang belum maju

\section{KESIMPULAN}

Dari konsep gagasan berbasis aplikasi yang penulis paparkan, dengan adanya aplikasi Smart Farmer tersebut maka akan membawa warna baru dalam dunia pertanian khususnya bagi kalangan masyarakat petani dan tentunya dalam pertumbuhan ekonomi pada masa pandemi covid-19, dimana konsep tersebut akan turut dalam meningkatkan jumlah produk pertanian yang terjual dan membantu petani dalam pemasaran produk pertaniannya serta mengatasi masalah rendahnya pemanfaatan teknologi di era society 5.0. Sehingga dalam jangka panjang tingkat pendapatan masyarakat kalangan petani bisa bertambah dan hasil pertanian akan bisa dimanfaatkan serta tidak terjadi pendiaman produk di gudang petani.

\section{SARAN}

Adapun saran dari penulis yaitu: Untuk pihak pemerintah baik itu pemerintah pusat maupun pemerintah daerah, aplikasi ini membutuhkan komunikasi/sosialisasi yang dilakukan oleh pihak pemerintah dan agent of change seperti kaum intelektual agar petani memahami apa, 
bagaimana, dan mengapa kegunaan dari aplikasi ini sangat penting untuk mulai menggunakannya. Untuk pihak dinas pertanian supaya tetap memberikan koordinasi terhadap para petani dan meyakinkan petani agar mempercayai gagasan Smart Farmer ini dalam memasarkan produk pertaniannya. Untuk pihak masyarakat petani supaya lebih percaya dan lebih semangat dalam menggunakan aplikasi Smart Farmer untuk mendukung perekonomian dan menambah penghasilan.

\section{DAFTAR PUSTAKA}

[1] D. Aigner, C. A. K. Lovell, and P. Schmidt, "Formulation and estimation of stochastic frontier production function models," Journal of econometrics, vol. 6 , no. 1, pp. 21-37, 1977.

[2] D. Apriadi and A. Y. Saputra, "E-Commerce Berbasis Marketplace Dalam Upaya Mempersingkat Distribusi Penjualan Hasil Pertanian," Jurnal RESTI (Rekayasa Sistem dan Teknologi Informasi), vol. 1, no. 2, pp. 131-136, 2017.

[3] L. Arsyad, . "Edisi 5, Universitas Gadjah Mada," Yogyakarta: Unit Penerbit Ekonomi Pembangunan dan Percetakan STIM YKPN, 2010.

[4] H. Kusniyati and N. S. P. Sitanggang, "Aplikasi Edukasi Budaya Toba Samosir Berbasis Android," Jurnal teknik informatika, vol. 9, no. 1, 2016.

[5] M. Muftizar, H. Ahmadian, and B. A. Majid, "Perancangan Media Interaktif Logika Pemograman Untuk Menarik Minat Belajar Siswa Pada SMK Negeri 1 Mesjid Raya," CIRCUIT: Jurnal IImiah Pendidikan Teknik Elektro, vol. 4, no. 1, pp. 61-72, 2020.

[6] D. Cahyadi, A. Faturahman, H. Haryani, and E. Dolan, "BCS: Blockchain Smart Curriculum System for Verification Student Accreditation," International Journal of Cyber and IT Service Management, vol. 1, no. 1, pp. 65-83, 2021.

[7] R. Rosyid and M. A. W. Prasetyo, "Robot Peraga 12 Gerakan Pengaturan Lalu Lintas Berbasis Arduino Mega 2560," Technomedia Journal, vol. 5, no. 2, pp. 193-205, 2021.

[8] B. D. Wicaksono and S. Anggraeni, "Perancangan Website Sistem Informasi Transaksi Tagihan Layanan Purna Jual Properti Pada Pollux Properti Indonesia," TMJ (Technomedia Journal) Vol. 5 No. 2 Februari 2021, p. 132, 2021.

[9] N. Cholisoh, J. Junaidi, and I. S. Sari, "Rancangan Sistem Penginputan Judul Online KKP, TA/SKRIPSI Berbasis Laravel Pada Universitas Raharja," Technomedia Journal, vol. 5, no. 2, pp. 248-258, 2021.

[10] S. Rahayu, A. Setiadi, and A. Muryanto, "Perancangan Sistem Pendaftaran Siswa Baru Secara Online Pada SMK Miftahul Jannah Cikupa," Technomedia Journal, vol. 5, no. 2, pp. 235-247, 2021.

[11] A. N. Nurhayati, A. Josi, and N. A. Hutagalung, "Rancang bangun aplikasi penjualan dan pembelian barang pada koperasi kartika samara grawira prabumulih," Jurnal

Teknologi Dan Informasi, vol. 7, no. 2, pp. 13-24, 2017.

[12] Y. Purbasari, "Rancang Bangun Aplikasi Penjualan Dan Persediaan Obat Pada 
Apotek Merben Di Kota Prabumulih," jsk (Jurnal Sistem Informasi dan Komputerisasi Akuntansi), vol. 1, no. 1, pp. 81-88, 2017.

[13] L. Sunarya, A. D. Purbayani, and N. Handayani, "Media Video Promosi Pada Roofpark Cafe \& Restaurant Pucak Bogor Jawa Barat," TMJ (Technomedia Journal) Vol. 5 No. 2 Februari 2021, p. 220, 2021.

[14] L. Sunarya, B. Abdurachman, and P. R. Ningsih, "Video Profile Balai Latihan Kerja Pada Dinas Ketenagakerjaan Kota Tangerang," Technomedia Journal, vol. 5, no. 2, pp. 206-219, 2021.

[15] S. W. Syahyuti, R. N. Suhaeti, A. K. Zakaria, and T. Nurasa, "Kajian Peran Organisasi Petani dalam Mendukung Pembangunan Pertanian," Laporan Hasil Penelitian. Pusat Sosial Ekonomi dan Kebijakan Pertanian. Bogor, 2014. 